\title{
Anti-Conflictualist and Liberal Minimalism of Rights: an Analysis from the Perspective of INTEREST TheORY AND THE DyNAMIC ApProACH
}

\section{Sobre el Minimalismo Anti-Conflictivista y Liberal: un ANálisis desde la Perspectiva de la INTEREST THEORYy DEL ENFOQUe DinÁMICO}

\section{Sobre o Minimalismo Anti-Conflitivista e Liberal: uma AnÁlise na Perspectiva da INTEREst THEORYE DA Abordagem DinÂMicA}

Michele Beniamino Zezza

\begin{abstract}
1 The minimalist approach and its historical-cultural presuppositions. 2 Anticonflictualist minimalism. 3 Liberal minimalism. 4 The unreasonableness of minimalism. 4.1. Some observations on interest theory and dynamic approach. 4.1.1 The recognition of equality of rights: some essential stages. 4.1.2 Critical arguments against minimalism. References.
\end{abstract}

\section{ABSTRACT}

The article describes two different miimalist approaches in the field of recognition and protection of rights: the anti-conflictual and the liberal variants. It explores their historical-cultural assumptions and highlights their main elements of their unreasonableness.

Methodology: To this end, we use some theoretical tools deriving from the combination of contemporary interest theory with a dynamic approach.

\footnotetext{
"Postdoctoral researcher in the Department of Direito do Estado of the Universidade de São Paulo (USP). Email: michele.zezza@for.unipi.it. The present work has been founded by the Fundação de Amparo à Pesquisa do Estado de São Paulo (FAPESP), with the following process number: 2017/24035-9. ORCID: https://orcid.org/0000-0002-4323-9850. E-mail: <michele.zezza@for.unipi.it>.
} 
Anti-conflictualist and liberal minimalism of rights: an analysis from the perspective of interest theory and the dynamic approach

Aim: One of the most relevant purposes of the research is to demonstrate the theoretical non-sustainability of those reconstructions which attributes to the historical succession of the different categories of rights a clear structural distinction between negative rights, understood as "self-executing", and positive rights to public provisions.

Achievement: The combination of these frameworks (dynamic theory and interest theory) provides a valid conceptual basis for the recognition of social rights in a parity plan regarding traditional rights of freedom; on the other hand, this position leads directly to the rejection of minimalism: classical civil liberties, just as the material conditions necessary for a dignified living, make up protected goods or interests of the subjects who demand positive benefits to be guaranteed.

Contributions: The work provides a philosophical research on the theoretical foundations of social rights in relation to the classical liberal rights of the first generation acquires a special relevance within the project. The present study looks forward to contributing to the unsustainability of those reconstructions that attribute to the historical succession of the different categories of rights a clear structural distinction between negative rights, understood as "self-executing", and positive rights to public benefits of the State.

Keywords: Anti-conflictualist minimalism. Liberal minimalism. Interest theory. Dynamic approach.

\section{RESUMEN}

El artículo describe dos enfoques minimalistas diferentes en materia de reconocimiento y protección de los derechos: las variantes anti-conflictivista y liberal. En ello, se reconstruyen sus fundamentos histórico-culturales y se destacan los principales elementos de su insostenibilidad teórica. Metodología. Para este fin, se utilizan algunas herramientas teóricas derivadas de la combinación de la interest theory contemporánea con un enfoque dinámico.

Objetivo: Uno de los propósitos más relevantes de la investigación es demostrar la no sustentabilidad teórica de esas reconstrucciones, que atribuye a la sucesión histórica de las diferentes categorías de derechos una clara distinción estructural entre derechos negativos, entendidos como "autoejecutivos", y derechos positivos a prestaciones públicas.

Resultado: La conjunción de estos dos planteamientos (teoría dinámica e interest theory) proporciona un válido fundamento conceptual al reconocimiento de los derechos 
sociales, en un plano de paridad respecto a los tradicionales derechos de libertad; por otra parte, esta posición lleva directamente al rechazo del minimalismo: las libertades civiles clásicas, de la misma manera de las condiciones materiales necesarias para una existencia digna, constituyen bienes o intereses protegidos de los sujetos que exigen prestaciones positivas para ser garantizados.

Contribuciones: El análisis realiza una investigación filosófica sobre los fundamentos teóricos de los derechos sociales respecto a los derechos liberales clásicos de la primera generación. Se produce, en este sentido, un desarrollo doctrinal de las bases conceptuales orientado a acabar definitivamente con la concepción canónica que defiende la superioridad axiológica de los derechos de la tradición liberal.

Palabras clave: Minimalismo anti-conflictivista. Minimalismo liberal. Interest theory. Enfoque dinámico.

\section{RESUMO}

$\mathrm{O}$ artigo descreve duas abordagens minimalistas diferentes em matéria de reconhecimento e proteção de direitos: as variantes anti-conflitivista e liberal. Nele, se reconstroem seus fundamentos histórico-culturais e se destacam os principais elementos de sua insustentabilidade teórica.

Metodologia: Para esse efeito, utilizam-se algumas ferramentas teóricas derivadas da combinação da interest theory contemporânea com uma abordagem dinâmica.

Objetivo: Um dos objetivos mais relevantes da pesquisa consiste em demonstrar a insustentabilidade teórica daquelas reconstruções que atribuem à sucessão histórica das diferentes categorias de direitos uma clara distinção estrutural entre direitos negativos, entendidos como “autoexecutivos”, e direitos positivos a prestações públicas.

Resultado: A conjunção dessas duas abordagens (teoria dinâmica e interest theory) fornece uma base conceitual adecuada para o reconhecimento dos direitos sociais em um nível de paridade em relação com os direitos tradicionais de liberdade; por outro lado, esta posição conduz diretamente à rejeição do minimalismo: as liberdades civis clássicas, da mesma forma que as condições materiais necessárias para uma existência digna, constituem bens ou interesses protegidos dos sujeitos que exigem prestações para serem garantidos.

Contribuições: A análise realiza uma investigação filosófica sobre os fundamentos teóricos dos direitos sociais em relação aos direitos liberais clássicos da primeira geração. Nesse sentido, produz-se um desenvolvimento doutrinal das suas bases conceituais com 
Anti-conflictualist and liberal minimalism of rights: an analysis from the perspective of interest theory and the dynamic approach

o objetivo de acabar definitivamente com a concepção canônica que defende a superioridade axiológica dos direitos da tradição liberal.

Palavras-chave: Minimalismo anti-conflitivista. Minimalismo liberal. Interest theory. Abordagem dinâmica.

\section{THE MINIMALIST APPROACH AND ITS HISTORICAL-CULTURAL PRESUPPOSITIONS}

Even from a superficial analysis of its historical development, one cannot but notice that, starting from post-World War II constitutionalism, the notion of subjective right has been affected by a significant process of transformation which has concerned both the level of the claims as much of the ascriptions. Alongside the multiplication of the social needs of citizens, also the number of rights' holders (individuals, communities, animals, plants, inanimate objects, future generations, etc.) has increased considerably, so to include on certain occasions new ${ }^{1}$ legal subjects and collective interests $^{2}$, as well as peculiar tools of legal recognition and protection.

Compared to previous phases in the evolution of rights - which dealt with the traditional individual freedoms and with economic, social and cultural rights - the most recent claims for rights display their own peculiar traits. Just to give some examples: issues such as the guarantees in the face of the risks posed by genetic manipulation, the rights of the embryo or the right to abortion, the right to development or to a sufficient life quality, have acquired, and continue to acquire, unquestionable relevance within the scenario of individual and collective claims that characterize contemporary constitutionalism.

We are indeed faced with a heterogeneous set of subjective situations that are difficult to include in the traditional classifications. In this sense, within the current globalized and multicultural societies, the claims that are considered as rights of fourth generation (collective rights and rights of solidarity) make up an increasingly open, dynamic and flexible catalogue, composed by rights that are rarely justiciable, or even not recognized by positive law. There is an increasing tendency within the legal and

\footnotetext{
${ }^{1}$ It must be stressed that those rights that, in the theoretical debate, are called "new rights", in reality, in most cases are reformulations (new interpretations or new applications) of already existing rights.

${ }^{2}$ As a first approximation, we can identify in the notion of interest the key element that justifies the attribution of a right. See for example Jhering ([1878], p. 328): the right to health, for instance, protects the interest in the individual's psycho-physical integrity; the right to education is intended to prevent the presence of treatment discrimination in the field of education, etc. Obviously, every substantial interest underlying a right necessarily presupposes complex relationships (of synergistic interaction or incompatibility) with other interests.
} 
philosophical reflection on latest rights to extend the notion of ownership to nonhuman subjects which, strictly speaking, are not entitled to full legal capacity and, in some cases, even to the ability to express their own will. In such a way, the result is a process of fragmentation of the original subject of rights, traditionally identified with an individual endowed with autonomy, rationality and intangibility.

The special configuration that the issues of the recognition and the entitlement of fundamental rights has acquired in today's constitutional states has determined, in recent decades, the development of a body of normative proposals that regard the problem of the anomic expansion of rights as one of the main factors behind the crisis of the so-called "age of rights". ${ }^{3}$ These approaches tend to highlight a relationship of inverse proportionality between the tendency - rather widespread in contemporary legalpolitical language - to conceive any claim as a right and their effective capacity to satisfy the interests and needs of people: the ever-wider recognition of the ownership of rights and the progressive increase of their instruments of judicial protection are thus accompanied by a continuous decrease in their effectiveness. ${ }^{4}$

In this sense, Roberto Bin observes that

the incongruency is pretty evident: as much as the sale of nobility titles is a prelude to the loss of their social meaning, so it is also for the constitutional status of "rights": to bestow the status of constitutionally-recognized right to interests that are borne out of extremely unsubstantiated interpretations makes less credible the attempt to use this status to repel other antagonistic interests, which do not possess a title of nobility (BIN, 2000, p. 23-24).

A further step in this direction is arguing that, in order to prevent morally and legally relevant assets from being weakened, it would be appropriate to limit the recognition and legal protection to those interests more closely linked to the traditional negative freedoms ${ }^{6}$, i.e. perfectly concluded in themselves, easy or immediate to implement, inherently non-conflictual and free of charge (or inexpensive). ${ }^{7}$ This argument also proposes a redefinition of the catalogue of rights (and of their guarantees) in a markedly deflationary manner. In this perspective, which in most cases takes a markedly normative valence, the restriction of the quantity of interests that are morally

\footnotetext{
${ }^{3}$ As is well known, such expression is utilized by Norberto Bobbio to highlight the significance that, despite delays and contradictions, the international movement for the protection of human rights has acquired since WWII. See Bobbio (1992).

${ }^{4}$ Zolo (1999, p. 16-18), talk about a "law of decreasing effectiveness of the guarantees of rights".

${ }^{5} \mathrm{My}$ translation. It should be noted that the author does not support a minimalist approach to rights.

${ }^{6}$ For the notion of negative freedom, the primary reference is to Berlin (1958).

${ }^{7}$ Emblematic versions of this perspective can be found in Cranston (1967), Ignatieff (2001), O'Neill (2005), Nozick (2011) and Nagel (2013). Critical settings towards the Welfare State, based on partially similar arguments, can also be found in: Buchanan and Tullock (1962), Hayek (1982), Offe (1984), Tropman (1989).
} 
Anti-conflictualist and liberal minimalism of rights: an analysis from the perspective of interest theory and the dynamic approach

and constitutionally legitimate is thus seen as a way to prevent the "real" rights from being weakened. ${ }^{8}$

The process of specification of goods and holders, the ever-wider diffusion of speeches, claims and appeals to rights, may result often in an increase of the possibility of conflict between rights themselves and an objective difficulty of protecting all formally recognized rights. In the reflections that follows, we intend to focus attention on two brands of minimalism particularly relevant within the philosophical-political and philosophical-juridical debate: 1) an approach that could be defined as "anticonflictualist", whose main purpose is to solve or limit problems of incompatibility between different rights; and 2) a "liberal" approach, which aims instead to restrict the body of rights to the fundamental freedoms of the classical liberal tradition. Although these two positions are generally confused under a single category, it seems appropriate to distinguish them at least from a conceptual point of view, keeping in mind that it is mostly a conventional categorization.

\section{ANTI-CONFLICTUALIST MINIMALISM}

As a general rule, the conflictualist approach tends to consider the problem of incompatibility between rights ${ }^{9}$ as an antinomical relationship, of "logical inconsistency" ${ }^{10}$, between norms (generally principles) conferring fundamental rights, imputable to subjects who are located in antagonistic position or even to the same subject. In this situation, the duties involved are not "compossible" or consistently applicable, as Hillel Steiner explains:

[t]he incompossibility of rights can assume either of two dimensions:
incompatibility may exist between different persons' exercises of different
kinds of rights; or it may exist between different persons' exercises of the same
kinds of right. My exercise of my right to free speech may interfere with your
exercise of your right to privacy; or my exercise of my right to free speech may

\footnotetext{
${ }^{8}$ A partially similar approach is the one defended by John Rawls in The law of peoples, in which the author extends the notions of 'justice as equity' and 'political liberalism', originally designed for individual national societies, in an international perspective, proposing in fact, on a global level, analogous ideas to those that libertarian critics of his theory had elaborated in relation to the initial stage of his theory. The number of human rights and the quality of their protection are limited, since in a theory of international justice they represent a constraint on sovereignty and are essentially linked to respect for self-determination. Human rights are therefore understood as a minimal threshold to be reached in order to become part of the Society of peoples. See Rawls (1999); on this point, see the criticisms of Griffin (2008, p. 22-27).

${ }^{9}$ For an introduction to the issue of conflicts between rights: (BESSON, 2005, p. 430-436; WALDRON, 1993; KAMM, 2001).

${ }^{10}$ For the distinction between "consistency" (logical compatibility) and "coherence" (substantial congruence) between norms, see Maccormick (1984).
} 
interfere with your exercise of your right to free speech. One objection that is sometimes registered to such exemplifications of incompatibility consists in claiming that they enjoy whatever damaging plausibility they appear to possess by trading on what are merely abbreviated descriptions of the rights involved (STEINER, 1977, p. 768). ${ }^{11}$

It is therefore an operational problem of application of the rules (who attribute fundamental rights), which occurs within the legal systems whenever it is not possible to meet all the recognized needs at the same time: the implementation of a right that belongs to an individual $x$ requires, for conceptual or factual reasons (i.e., abstractly or concretely), the lake of fulfilment of another right (which may also represent another instance of the same right) of an individual $y$.

In opposition to this understanding, several normative approaches deny that, in the abstract, genuine cases of collision between rights occur, or states that in case they occur during the application phase, they can be resolved by establishing which right should prevail ${ }^{12}$. According to this perspective, the mistake usually committed in detecting a conflict between rights lies in the failure to specify the antecedent of the rules which attribute fundamental rights. In a situation of alleged conflict, either one of the two rights involved is not an authentic right, or the exact perimeters of one (or both) of them are being ignored. ${ }^{13}$ Rights would come into conflict only in their generic formulation, but would then prove to be susceptible of specification, identifying a third rule whose formulation would make the appearance of conflict disappear. Such goal is shared by various philosophical-political and philosophical-moral approaches: to build a normative system of rights in which conflicts tend not to occur ex ante.

Within the philosophical-political debate, an illuminating example of this first form of minimalism is the argument developed by Robert Nozick to neutralize the clash between rights at the level of the (minimal) state theory. This position is notably part of a wider project of utopian transformation of society: it is within this framework, therefore, that we need to place also the intention to restrict the category of interests which can aspire to the qualification of "rights" exclusively to the classical negative freedoms of abstention. These spaces of freedom can then operate as "side-constraints": like certain collateral, absolute and negative limits to people's conduct. ${ }^{14}$ Although the

\footnotetext{
11"A possible set of rights is such that it is logically impossible for one individual's exercise of his rights within that set to constitute an interference with another individual's exercise of his rights within that same set." (STEINER, 1977, p. 769).

${ }^{12}$ Among normative theories, significant examples can be found in: (DE OTTO, 1988; HABERMAS, 1996; MARTÍNEZ PUJALTE, 1997; JIMÉNEZ CAMPO, 1999; CIANCIARDO, 2000; OLLERO TASSARA, 2000; SERNA BERMÚDEZ; TOLLER, 2000; MORESO, 2003, 2004).

${ }^{13}$ See Smith (1995), in particular p. 150-151.

${ }^{14}$ See Nozick (2011, p. 47-48). This side-constraint view reflects the underlying Kantian principle of individuals as ends in themselves, on the basis of which the rights of an individual cannot be violated
} 
Anti-conflictualist and liberal minimalism of rights: an analysis from the perspective of interest theory and the dynamic approach

author does not clearly explain its content, from a global analysis of Anarchy, State and Utopia emerges the strongly individualistic inspiration of the theory, centred on the idea of the inviolability of the person: rights, in this perspective, express the basic idea that individuals cannot be exploited for the achievement of other ends without their consent.

To understand the scope of this discourse it is necessary to start from the problem of the origin of goods ownership. In this regard, the one developed by Nozick is a pure theory of the valid title ("entitlement theory"), aimed at determining whether people are entitled to what they possess, which is structured around three assumptions: 1) the principle of justice in acquisition, that deals with the initial acquisition of holdings (how people first come to own unowned and natural world goods, what types of objects can be held, etc.); 2) a principle of justice in transfer, that explains how one person can acquire holdings from another, including voluntary exchange and gifts; 3) a principle of rectification of injustice, that explains how to deal with holdings that are unjustly acquired or transferred, whether and how much victims can be compensated, how to deal with long past transgressions or injustices done by a government, and so on. ${ }^{15}$ Regarding the latter point, in theory, this principle requires redress as to possible injustices committed through previous acquisitions and transfers: it may imply, therefore, even substantial compensation in benefit of those who have been illegitimately harmed. In some contexts, although for a limited time, a strong state interventionism will be necessary in order to improve the situation of the most penalized subjects and social groups. Nevertheless, it should be noted that Nozick does not provide any systematic explanation in relation to when and to what extent the abuses of appropriation - the acquisition of property in conditions of scarcity for the rest of the community - must be modified or sanctioned. ${ }^{16}$

This perspective, aimed at highlighting the conditions of legitimacy of the private appropriation of natural resources, is openly based on the theory of work and property developed by John Locke in the Second Treatise on Civil Government, who in particular in par. 27 offers a logical reconstruction of the process of appropriation of things by individuals. In this sense, Nozick takes up the classical theory of the state of nature, understood as that condition in which each person can reach a certain level of wellbeing according to their abilities. This level of welfare, while not equal, must be maintained via what the author defines the "Lockean proviso" ${ }^{17}$, according to which self-

to avoid violations of the rights of other people.

${ }^{15}$ See Nozick (2011, p. 152-153).

${ }^{16}$ For a criticism at Nozick's individualism as indifferent to the economic-social needs of collective wellbeing, see Hart (1979, p. 828-846).

${ }^{17}$ See Nozick (2011, p. 175-182). On the Lockean theory, see in particular Macpherson (1962), Tully 
ownership provides to a person the freedom to blend his or her labour with natural resources, converting common property into private property. ${ }^{18}$ In the Nozickean reinterpretation, the proviso implies that, although every appropriation of property represents a diminution of another individual's rights to it, it is acceptable as long until it worsens the condition of no individual than they would have been without any private property. ${ }^{19}$ Every person - argues Nozick - will thus only have to worry about respecting those constraints that make possible the rights of others: the possible violation of person A's right does not justify that person $B$ should try to avoid it. Every individual has total and exclusive dominion over his own person, provided that he also respects the ownership that others have over themselves.

Based on these premises, therefore, rights are configured as the "boundaries" that delimit the legitimate and inviolable sphere of action of individuals. Such barriers cannot be crossed without the consent of those same individuals, by definition entitled to freely build their own future, thus making unjustified any action or political measure that imposes any sacrifices on them. Within this reconstruction, the only conceivable positive rights are those that result from voluntary transactions between people (such as those that arise when contracting certain essential services).

On the foundation of this normative and deontological proposal one can identify the claim to define the content of rights by considering their purely semantic aspects: the problem of compatibility between fundamental rights, in this perspective, is presented as exclusively definitive or stipulative, depending largely from the notion of rights previously accepted.

\section{LIBERAL MINIMALISM}

Constitutions - critics of the Welfare State often argue - are legal documents whose functions are intrinsically limited: if we tried to make all the claims contained in them binding and enforceable, we would end up undermining even the traditional negative freedoms of the liberal rule of law.

(1980) and Kramer (1997).

${ }^{18}$ Locke's labour theory of property has been criticized by Nozick himself, who doubt the idea that adding something owned to an object unowned could imbue this last one with ownership. In this regard, the author asks: “why isn't mixing what I own with what I don't own a way of losing what I own rather than a way of gaining what I don't? If I own a can of tomato juice and spill it in the sea so that its molecules (made radioactive, so I can check this) mingle evenly throughout the sea, do I thereby come to own the sea, or have I foolishly dissipated my tomato juice?" (NOZICK, 2011, p. 174175). Similarly, Jeremy Waldron believes that Locke has made a "category mistake" (more precisely, a semantic error consisting in improperly attributing property to an object), since work is an activity that is not identifiable with physical objects (see WALDRON, 1983, p. 37-44).

${ }^{19}$ On this subject, see (WOLFF, 1991; AI-THU, 1995; WALDRON, 2005). 
Anti-conflictualist and liberal minimalism of rights: an analysis from the perspective of interest theory and the dynamic approach

Following this line of reasoning, they uphold that the complex of rights recognized by constitutional texts should be limited (or should recognize their superiority) to traditional civil and political freedoms. Thereby, a clear, axiological, distinction between "self-executing" rights (the civil and political rights of first and second generation ${ }^{20}$ ) and public benefit rights or credit rights for the state (social, economic and cultural rights, as well as fourth generation rights) is attributed to the historical succession of the different categories of rights. In this perspective, the former ones impose mere abstentions on the State (avoiding killing, torturing, imposing censorship, etc.), while the latter ones mostly require it to fulfil positive obligations (disbursement of public funds, provision of health or education services, etc.). On the other hand, the other rights are frequently described as interests whose implementation requires a plurality of public interventions, mainly financed through taxation, and thus potentially damaging individual property rights.

According to this perspective, social rights (those rights meant to neutralize certain forms of inequality present in society $)^{21}$, in particular, as well as all rights in which the provision of positive performance is a constituent part of their own logical structure $^{22}$, are represented as expectations of services that consume large amounts of community resources. In other words, they are seen merely as "conditional opportunities" 23 , inevitably tied to the discretionary choices of the administration, and whose implementation depends to a large extent on the availability of resources. Given the natural scarcity of resources, these rights are frequently represented as interests that, when put into effect, risk causing inefficiencies in the economic system, by placing them in a condition of structural competitiveness in accessing community assets. ${ }^{24}$ Based on this interpretation, the effectiveness of socio-economic, cultural and new generation

\footnotetext{
${ }^{20}$ See, for example, Fried (1978) and Cranston (1967, p. 50) ("civil and political rights are not difficult to institute. For the most part, they require Governments, and other people generally, to leave a man alone [...] generally they can be secured by fairly simple legislation").

${ }^{21}$ The redistributive function of social rights is underlined in particular by Marshall (1992), which considers social rights as qualitatively new determinations of the status of citizenship in tension with the market, given that their inclusion implies the creation of a right to receive an income not proportionate to the market value of the person claiming it. In this regard, please refer also to Zolo (1994, p. 33-34), who notes that effective fulfilment of social rights is incompatible with the ideal of market efficiency, and therefore can only pass through a profound revision of the structures of the capitalist economy. Lastly, see Rodotà (1992, p. 117-120), according to which the recognition of social rights represents an alternative to the logic of market self-sufficiency.

${ }^{22}$ See, in this sense, Prieto Sanchís (1998, p. 74-76), Celano (2001, p. 54-56), Abramovich and Courtis (2004) espec. pp. 31-36. See also the reflections on "positive rights" (claims of a positive action by others) developed in particular by Feinberg (1973, p. 59-60) and MaCcormick (2007, p. 123-13).

${ }^{23}$ This expression was initially used by Barbalet (1988).

${ }^{24}$ For a similar position see Corso (1996), which refers to the idea of a "distributive conflict" between the different holders of social rights, also using the metaphor of subtraction as an effect of a continuous accumulation of rights. Similarly, Pintore (2004), speaks of a "zero-sum game" within which some rights are in fact not upheld so to make room for the protection of other rights.
} 
rights is dependent to a large extent on choices on how to redistribute national wealth (for example, in the case of health care or public education), while civil and political freedoms can be guaranteed regardless of the economic conjuncture, without affecting the liberal architecture of society.

For instance, on the jurisprudential level, we can considered the particular treatment reserved to national fundamental (in particular social) rights by the Court of Justice of the European Union roughly in the last two decades: net of some fluctuations $^{25}$, the most frequent scenario that summarizes its legal reasoning in this regard is that member states can apply the rights recognized within their respective systems until they interfere with the application of European law and with the uniform prevalence of the rights and freedoms recognized and regulated by it. In this regard, there are numerous decisions of the Court of Justice which show, in general, that social rights can only be recognized (be raised to the status of a fundamental right) only if they contribute to attributing relevance to traditional economic freedoms of movement, capital, people, goods and services (the four freedoms of the common European market. ${ }^{26}$ It is no exaggeration to assert that, in many cases, social rights (especially labour rights and rights related to social security systems) are "functionalized" to the competitiveness needs of the European common market, of the free competition and more generally of the economic development. In this way, more or less consciously depending on the case, the theoretical distinction between the different generations of rights ends up legitimizing the unfavourable treatment that the rights of the third and fourth generation usually receive.

This dichotomy, being devoid of any logical backing, it must be rejected. In the considerations that follow, we will highlight the main aporias that undermine the minimalist model in both its variations.

\footnotetext{
${ }^{25}$ It should be noted that, in some relatively recent judgments, the Court seems willing to limit "fundamental freedoms" in order to protect "fundamental rights" as recognized by national constitutional traditions and by the ECHR, thus orienting towards a placement of rights and freedom on an equal footing. See, in particular, of the Court of Justice: $26^{\text {th }}$ of June 1997, case C-368/95, Familiapress; $12^{\text {th }}$ of June 2003, case C-112/00, Schmidberger; $14^{\text {th }}$ of October 2004, case C-36/02, Omega. Finally, in the judgement Albany International BV contra Stichting Bedrijfspensioenfonds Textilindustrie (C-67/96, 1999) the Court has stated that the right to collective bargaining can be subtracted from competition law.

${ }^{26}$ Among the most representative judgments, one can consider the decisions regarding the right to strike (sent. Viking: C-438/05, 2007), the trade union struggle (sent. Laval: C-341/05, 2007) and the minimum wage (sent. Rüffert: C-346/06, 2008); see also the sent. Commission of the European Communities v Grand Duchy of Luxemburg (C-319/06, 2008).
} 
Anti-conflictualist and liberal minimalism of rights: an analysis from the perspective of interest theory and the dynamic approach

\section{THE UNREASONABLENESS OF MINIMALISM}

Since minimalism aspires to be a philosophical-political project of social transformation, its unreasonableness cannot to be found exclusively in its impermeability to the conditionings of the positive law. However, it should be noted that considerably moves away from the legal reality the claim, advanced by minimalist theorists, to analyse the relations between rights through a linguistic and conceptual analysis in which the semantic level is completely separated from the concrete context of their implementation. In the field of legal interpretation and jurisprudential practice, in most cases, the determination of the boundaries of a right imposes a work of proportioning and balancing with other potentially conflicting rights within the circumstances of the specific case. ${ }^{27}$

Cristopher Wellman, in particular, in evaluating the Nozickian proposal, notes that not even such a configuration of the relation between rights could exclude the possibility of conflicts between negative rights. ${ }^{28}$ Similarly, Bruno Celano states that even a minimalist set of classical liberal rights, in order to be plausible, should include a plurality of rights that can clash with one another (and cause conflicts between correlative duties), as well as the establishment of open clauses, limitations and "thick ethical terms". 29

The constitutional discipline of rights shows that the protection of any right always depends on a body of jurisdictional guarantees put in place by public subjects. The widespread recourse to balancing techniques, proportionality tests and reasonableness criteria, as well as the continuous regulations (specifications, determinations of content) that the constitutional courts and the common courts apply to all types of rights, demonstrate that even the exercise of freedom rights can be gradual and bound to the material and juridical resources available in a given context. ${ }^{30}$

Therefore, the traditional civil and political rights (personal freedom and freedom of movement, freedom of association and assembly, inviolability of the home,

\footnotetext{
${ }^{27}$ Andrei Marmor, in this regard, stigmatizes the "Newtonian" conception of rights, aimed at representing them as autonomous entities that move freely in an empty moral space until they encounter an external limit resulting from the collision with other rights (see MARMOR, 1997).

28 "Rejecting positive rights cannot solve the problem of conflicting rights." (WELLMAN, 1999, p. 273).

29"Even a Bill of Rights that limits itself to enshrining the freedom rights (rights of the first, or the very first, generation), thus reducing to the essential the catalogue of constitutionally recognized rights, provided that it is reasonable and sensible, can generate conflicts and tensions between those rights, and between them and other objectives or socio-political values; and thus generates the indeterminacy and uncertainty typical of contemporary constitutions." (CELANO, 2013, p. 96, my translation).

${ }^{30}$ On the coexistence of negative and positive dimensions in rights, see in particular Waldron (1993, p. 214) ("one and the same right may generate both negative and positive duties"); Ferrajoli (2007, p. 325, 327) and Holmes and Sunstein (1999).
} 
private property, etc.), generally associated with the typical functions of the liberal rule of law, require positive interventions such as the establishment of bureaucratic, administrative and judicial systems, the development of rules and regulations, the exercise of police power, and other functions. One can considerer, for example, the right to democratic participation, which in practice require much more than mere abstention on the part of the State, since some political structures that provide adequate space for popular participation are always necessary. ${ }^{31}$

At the same time, not even the socio-economic, cultural and the new fourth generation rights can be seen exclusively as the result of positive obligations: even when their holders have already had access to the good that is the object of the right in question, the state power will continue to have to refrain from carrying out those behaviours that could damage it (for example, in the case of the freedom to unionize or the right to strike), and to use appropriate control measures to prevent and sanction any violations. In this regard, J.A. Cruz Parcero correctly points out:

when talking about the right to education, we immediately think of the
positive obligation of the State to provide education, build schools, pay
teachers, give scholarships, etc.; but, in turn, the State has passive obligations
of not worsening education, of not expelling children from schools, of not
denying access to education (under certain circumstances), of not charging
tuition or fees when education is free, etc. (CRUZ PARCERO, 2007, p. 76,
my translation).

Furthermore, it cannot be overlooked that the same public funds used to finance the protection of rights can constitute, in a future-oriented perspective, a productive investment to increase collective well-being. To this end, partially taking up a thesis by Amartya Sen - which highlights the connection between the economic, industrial and technological development of Japan and China at the beginning of the $20^{\text {th }}$ century and the investments in education and scientific research carried out in the previous period Luigi Ferrajoli rightly maintains that "if it is true that fundamental rights have a cost, it is also true that violating or not implementing them costs much more." ${ }^{32}$ Especially in contemporary democracies, characterized by a close link between economic, cultural and technological progress, the recognition and protection of essential rights such as access

\footnotetext{
${ }^{31}$ In this regard, Jeremy Waldron writes: "[r]eflection on the rights of the citizen also undermines the claim that first generation rights call only for inaction by the state, rather that collective intervention. In fact, rights to democratic participation require much more than mere omissions by the state. They require officials to approach their task in a certain spirit, and they require the establishment of political structures to provide a place for popular participation and to implement people's wishes, expressed by voting and other forms of pressure." (WALDRON, 1999, p. 343).

${ }^{32}$ See Ferrajoli (2007, p. 67-71, my translation) and Sen (1984).
} 
Anti-conflictualist and liberal minimalism of rights: an analysis from the perspective of interest theory and the dynamic approach

to food, social security, health or education are the basis for individual survival, but also for the socio-economic development of the whole community.

\subsection{SOME OBSERVATIONS ON INTEREST THEORY AND DYNAMIC APPROACH}

\subsubsection{The recognition of equality of rights: some essential stages}

Leaving aside the analysis of Nozick's theory, it can be observed that, in general terms, the minimalist proposal tends to rest on the identification between rights and legal obligations. Put it simply, based on this approach, we tend to consider as worthy of protection only those goods (authentic, genuine, free, etc.) whose legal guarantees have been arranged (or can easily be arranged).

A possible way to overcome some problematic aspects inherent in this approach is offered by contemporary interest theory combined with a dynamic perspective ${ }^{33}$ : the idea that the same constitutional right can lead to further rights, claims and obligations on third parties, in ways that are not always foreseeable. ${ }^{34}$

Although there are significant differences in this regard, according to M.H. Kramer all the doctrines that are classified under the name of 'interest theory' adhere to two kinds of principles:

(1) [n]ecessary but insufficient for the actual holding of a right by a person $X$ is that the right, when actual, preserves one or more of X's interests. (2) X's being competent and authorized to demand or waive the enforcement of a right is neither sufficient nor necessary for $\mathrm{X}$ to be endowed with that right (KRAMER, 1998, p. 62.

According to the author, the decisive condition is the latter: since competence presupposes the ability to choose, if a person is not morally or legally competent, he cannot even be morally or legally authorized. This is the main reason why, for supporters of choice theory, children or people who are unable to understand and want,

\footnotetext{
${ }^{33}$ The fact that the dynamic approach, most of the time, seems closely linked to different forms of interest theories can be seen as historically contingent and devoid of logical necessity. On this point see Sumner (1987, p. 39 ff., 51-53, 96 ff.), who elaborates a version of choice theory which accepts the essential theses of the dynamic conception.

${ }^{34}$ The dynamic approach - observes Celano - "sees a subjective right as the germinal nucleus of determined normative positions, or specific sets of such positions, as the ratio that explains and justifies the attribution or recognition of specific regulatory positions." (CELANO, 2001, p. 6.). Dynamic approaches can be found in: (MACCORMICK, 1976, 1977, p. 188-201; SUMNER, 1987, p. 51-52; WALDRON, 1988, p. 79-87; WALDRON, 1993, p. 212-214; RAZ, 1986; 1994; FEINBERG, 1970; LYONS, 1994).
} 
since they lack the ability to control and determine their choices, are not considered rights bearers. In other words, rights are claims accompanied by a power: without power you can have a claim, but you have no right. On the other hand, according to the advocates of interest theory, the possession of a right does not depend on the possession of legal powers but only on the fact that this right protects the interests of people.

The most complete elaboration of an approach of this type conjugated with a dynamic conception has its roots, in 1970's in some works of Neil MacCormick (and later developed especially by Joseph Raz, Jeremy Waldron and Andrei Marmor), in which the author raises a series of objections to the Hartian perspective, opting instead for a different view of rights, understood as "favourable situations" of an argumentative or justificatory nature. ${ }^{35}$

Before illustrating this position, however, it is necessary to take a step back. According to H.L.A. Hart, in short, it is necessary to find the meaning of the terms referable to the lexicon of rights in that single element common to the different notions (or most of them) that are part of it. Analysing the peculiar version of "benefit theory" put forth by Jeremy Bentham ${ }^{36}$, Hart $^{37}$ states that being the beneficiary of the fulfilment of a legal obligation does not constitute a necessary or sufficient condition to hold a right correlative to such obligation. On the contrary, it is both necessary and sufficient that the holder has the power to control on the obligation related to that right.

The perspective of choice or will theory ${ }^{38}$, "centred on the notion of a legallyrespected individual choice" (HART, 1982, p. 189), could not be considered exhaustive of the notion of subjective right ${ }^{39}$, as it does not provide adequate indications for all those cases where it seems appropriate to use the language of rights with reference to basic human needs, fundamental freedoms and those goods and services essential for

\footnotetext{
${ }^{35}$ See N. MaCcormick $(1976,1977)$. Some anticipations of the theses formulated by MacCormick can be found in Lyons (1994).

${ }^{36}$ The core of the 'benefit theory' of rights, in the version developed by Jeremy Bentham, can be summarized in the following terms: "this identification of a right-holder by reference to the person or persons intended to benefit by the performance of an obligation." (HART, 1982, p. 169).

${ }^{37}$ See in particular (HART, 1955, in WALDRON, 1984, p. 35; HART, 1982, p. 162-193). On the position taken by Hart since 1955, see (WALDRON, 1993, p. 366-367).

${ }^{38}$ Although even in this case there are some differences, according to M.H. KRAMER, proponents of choice theory (the approach that justifies the attribution of a right as a way to protect a choice) share three principles: "(1a) [s]ufficient and necessary for $X$ 's holding of a right is that $X$ is competent and authorized to demand or waive the enforcement of the right. (2a) X's holding of a right does not necessarily involve the protection of one of more of X's interests. (3a) A right's potential to protect one or more of X's interests is not sufficient per se for X's actual possession of that right" (KRAMER, 1998, p. 62). Emblematic versions of choice theory can be found in (HART, 1982; SIMMONDS, 1998; STEINER, 1998, p. 233-301; WELLMAN, 1997).

${ }^{39}$ On the limits that Hart himself recognizes in choice theory see Finnis (1980, p. 204-205).
} 
Anti-conflictualist and liberal minimalism of rights: an analysis from the perspective of interest theory and the dynamic approach

the preservation of the dignity of the individual. ${ }^{40}$ By virtue of its features, this approach cannot represent the only possible explanation for subjective rights (HART, 1982, p. 189): in some cases, it is thus possible to argue that at the heart of the notion of subjective right, rather than in the possibility of choice by the right holders, one have to find in the notion of fundamental needs. This occurs mainly in two areas: that of rigid constitutional systems - in which rights constitute formal and substantial limits for the legislator - and in the context of moral evaluation, that is, in a radically different framework than that than constituted by the "standard" vocabulary of rights.

Hart himself, in other words, despite placing much emphasis on individual choice in his definition of the notion of subjective right, acknowledges that voluntarist conceptions fail to account for those expectations whose fulfilment is not left to a potestative act of ownership (the faculty to determine the behaviour of another subject), but depends on someone else's initiative. Such theories do not seem able to capture the notion of a subjective right which, based on some fundamental needs, would be alien to the technical-legal language ordinarily employed by judges, lawyers, jurists, belonging rather to "a peculiar form of moral criticism of the right." (HART, 1982, p. 192-193)." 41 The validity of the choice theory, therefore, would be limited to the explanation of some legal rights: of those cases in which the holder of a right is in a position to exercise power over the recipient of the duty. On the other hand, Hart recognizes that this approach proves inadequate to explain certain issues related to the protection of human well-being and development: in these cases, the notion of benefit or interest allows us to explain the way in which the individuals are protected through "immunity-rights" (to which they correspond "disabilities" for the legislator), from the abuses of organized state power (HART, 1982, p. 168-169). ${ }^{42}$

\footnotetext{
${ }^{40}$ Following the reconstruction of Luigi Ferrajoli (2001, p. 298-299), it can be assumed that basing rights means asking the problem of determining their value substrate and providing the reasons why they must be recognized from the legal system. On a general level of normative ethics, in a "philosophicalpolitical" or "theory of justice's" perspective, founding human rights is equivalent to making explicit the arguments in favour of their existence and their legitimacy. According to this reasoning scheme, we can identify the foundation of human dignity in the value of individual existence as owner of moral rights and duties (see in this sense HABERMAS, 2001).

${ }^{41}$ In relation to the specific case of welfare rights, Hart believes that these rights can be claimed through a will theory perspective in at least two cases: when the provision of the positive benefit covered by the right is subject to an explicit request by the holder of the right, and when the law provides for some means of enforcement in case the service has not been provided. However, the case whereby the owner of a duty related to certain social rights is not identifiable or, for other reasons, where the service is not due cannot be traced back to a voluntarist approach (HART, 1982, p. 185-186).

${ }^{42}$ Simplifying: an individual $X$ has a legal immunity towards an individual $Y$ if the latter does not have the power to (is unable to) modify the legal position of $X$. They note how it is possible to account for immunity-rights on the basis of a voluntarist approach: (MACCORMICK, 1977, p. 194-195; BAYLES, 1992, p. 147). In a first phase of his reflection - it must also be specified - Hart is inclined to explain the notion of immunity through a choice theory perspective (see HART, 1983, p. 35 n.).
} 
Relying on these insights, it will be mostly Neil MacCormick who will deconstruct the standard (back then) theory, by introducing a series of counterexamples to show that some right holders may not have any power over the correlative obligations of other subjects. The paradigmatic example, as we know, is that of children's rights: it is certainly possible to argue that every child has the right to receive an education, without yet knowing precisely who must have the corresponding obligation and the power to provide for it (MACCORMICK, 1976, p. 305-313). ${ }^{43}$ A second example refers instead to other inalienable right holders, in particular in the field of work relationships and bargaining power, who have full capacity to act but who, for different reasons, do not make use (or cannot make use of) of any power to choose between the fulfilment or the correlative non-obligation (MACCORMICK, 1977, p. 196-197). According to MacCormick, therefore, legal provisions do not in themselves constitute a right, but are essential for its implementation, "because they protect the rights of children" (MACCORMICK, 1976, p. 308). ${ }^{44}$ When it is stated, for example, that a child has the right to be fed, it does not mean simply that someone else has a duty to feed him, but that the satisfaction of his interest is an end in itself, and not a means of achieving further ends (MACCORMICK, 1976, p. 159).

Now, one of the main critical points of this theoretical orientation is that to the existence of a moral right (and the related moral duty) does not always correspond a legal duty: in other words, the risk inherent in this approach would be to disown the relevance of the authoritative adoption of binding decisions. In this regard, MacCormick argues, however, that may exist legal rights (not just moral rights ${ }^{45}$ ) that are unrelated and logically antecedent with respect to legal duties: the function of rights is in no way reducible to that of mere correlatives of duties or other juridical positions. A

\footnotetext{
${ }^{43}$ On this subject, see the analyses of Fanlo Cortés (2008). For a reconstruction of the Hart-MacCormick debate, see Celano (2013), especially p. 54-65.

${ }^{44}$ MacCormick himself, however, does not disregard the relevance of individual choice in the exercise of a subjective right ("[i]t is certainly true that apart from such cases as those of children or the mentally incapacitated, the holder of a legal right is normally permitted and empowered in law to choose whether or not on any given occasion he should avail himself of his right." (MACCORMICK, 1976, p. 314).

${ }^{45}$ In broad terms, with the expression 'moral rights' we can mean those ideal rights that arise from the ethical dimension of the existence of the individual, prior to social institutions, which in order to be affirmed or claimed do not require any legal, institutional or conventional recognition. Particularly clarifying, in this regard, is the reflection of Carlos S. Nino who, reformulating a definition by (MACCORMICK, 1982, p. 160), characterizes moral rights in these terms: "[t]he right of access to a situation $\mathrm{S}$ is assigned to someone (which may be the possibility of performing a certain action or having certain resources or being free of certain contingencies) when the individual in question belongs to a class $\mathrm{C}$ and it presupposes that $\mathrm{S}$ normally implies for each member of $\mathrm{C}$ an asset of such importance that its access to $\mathrm{S}$ must be facilitated and it is morally wrong to prevent such access, whatever the consequences of such access with respect to aggregate values" (NINO, 1989, p. 40, my translation). In this perspective, evidently, the only condition for attributing moral rights to a subject is that of the moral person (the class $\mathrm{C}$ of the definition provided by the author).
} 
Anti-conflictualist and liberal minimalism of rights: an analysis from the perspective of interest theory and the dynamic approach

possible answer to this problem can be found in the distinction, elaborated by Ferrajoli, between primary guarantees (positive or negative obligations, borne by private individuals and/or public authorities, correlated to a right) and secondary guarantees (the obligation for the judges to sanction with annulment or with conviction the invalid or illegal acts in which the violations of the primary guarantees occur). ${ }^{46}$ According to the author, although the rights consist of "negative or positive expectations to which they correspond obligations (of provisions) or prohibitions (of injuries)" (FERRAJOLI, 2001, p. 11, my translation), and therefore the obligations and prohibitions that correspond to them, as well the related obligations to repair or punish judicially the injuries of rights, are "logically implicated by the normative statute of rights", in practice, it often happens not only that these obligations and/or prohibitions are violated, but also that they are "not even established by law" (FERRAJOLI, 1998, p. 11). Nevertheless, the lack of protection mechanisms at the level of the infraconstitutional law, and in particular as regards the apparatus of jurisdictional guarantees, does not annul the existence of a right, but rather configures a lacuna within the legal system (FERRAJOLI, 2013, p. 53-54). In this case, the charge of filling the lacuna relies on the legislator or on the judge-interpreter: in the event that the related meta-obligation remains unfulfilled, however, the problem of identifying the secondary guarantees of the right in question will persist.

\subsubsection{Critical arguments against minimalism}

According to the supporters of interest theory, the greater effectiveness of such approach depends mostly on its capacity to justify the recognition, at least on a prepositive moral level, of social rights ${ }^{47}$ and of rights attributed to subjects who are not able to express their will (children, disabled people, future generations, etc.). On the basis of this perspective, it is possible to recognize the existence of a right when a certain interest (its justifying element) is considered sufficiently important to attribute to a titular subject a series of favourable subjective positions (freedom, claims, powers and immunities), and to impose on another subject (not necessarily a specific individual) the correlative positions necessary to protect it. Thus, cases in which the owners are not

\footnotetext{
${ }^{46}$ See Ferrajoli (2007) vol. I, p. 196-198, 668-701, 2016, espec. capp. II, III.

${ }^{47}$ As Alessandra Facchi recalls, however, "supporting the key relevance of individual will does not mean excluding the importance of economic and social rights." (FACCHI, 2008, p. 325, my translation). In this sense, there is no impediment, in principle, for a justification of social rights that makes reference to a will or choice theory perspective. On the compatibility between interest theory and (protection of) social rights see Waldron (1984, p. 11-12, 1993, p. 16-17). For a position that places the foundation of social rights in the respect for individual autonomy see Fabre (2004).
} 
actually able to exercise them by making free and conscious choices can also be included in the list of rights. ${ }^{48}$

Furthermore, this theory would also be able to include a range of broader options among the possible justifications for rights, by accepting different values (principles, goods, needs, etc.) as justifications for the recognition of rights, which includes also the protection of individual freedom. A doctrinal reconstruction that identifies the generative nucleus of rights in the protection of an individual or collective interest may accept different values as justifying elements of the recognition of rights, by resulting mostly open in front of the changing of the social reference framework. This approach, which recognizes, as it might be said, a "sufficient foundation" 49 or "different possible foundations" $" 50$ of rights, seems more compatible with a context of ideological pluralism such as that which characterizes contemporary constitutionalism.

Rights are thus seen as ethical-juridical requirements that constitute the core of a plurality of positions and of subjective duties ("grounds of duties") ${ }^{51}$; complex positions which include both features of "positive" intervention and "negative" abstention, and from which various "waves" of not-predeterminable specific subjective positions spring. Celano observes on this point:

[f]or those who adopt choice theory, it is difficult to find reasons to believe
that basic human needs and interests are the basis of rights. If, on the other
hand, interest theory is adopted - that is, if it is assumed that there is a right
wherever there is an interest (a good) that must be protected, or satisfied (an
interest sufficiently important to justify an obligation for others) - the
possibility to qualify what constitutes the object of fundamental human needs
or interests or the subject of other rights presents no conceptual difficulty.
According to this perspective, freedom rights are seen as a particular class of
rights, equal to and coordinated with others. As much as life and the material
conditions necessary for a dignified existence, also freedoms are assets that
must be assured to individuals (they are interests that must be protected)
(CELANO, 2001, p. 51-52, my translation).

Interest theory, combined with a dynamic perspective, tends to attribute the same theoretical dignity to the different generations of rights, even when certain interests have not yet been accepted by a positive legal order and their claim makes sense only from the point of view of moral criticism of the law. In this regard, the validity of the approach in question seems to be confirmed by the effective functioning of fundamental rights: in addition to the negative abstention profiles, it always requires, for the purposes

\footnotetext{
${ }^{48}$ See for example Kramer (1997, p. 64).

${ }^{49}$ See Perelman (1968).

${ }^{50}$ See Bobbio (1992).

51"The essential point is, however, that rights are grounded in the interests of the potential right holder, and that duties are grounded in rights." (MARMOR, 1997, p. 3-4).
} 
Anti-conflictualist and liberal minimalism of rights: an analysis from the perspective of interest theory and the dynamic approach

of their implementation, a complex work of determination (specification, concretization, delimitation) of their content through the creation of appropriate institutes, rules and regulations, and of procurement of the necessary economic and financial resources. ${ }^{52}$

This reconstruction of the meaning of rights provides several theoretical elements to reject the economistic logic ${ }^{53}$ that assigns a central importance to the "principle of necessity" imposed by markets, and by monetary and banking institutions: a sort of jurisprudential orientation that assigns to social rights a role of instrumental subordination with respect to economic objectives. This kind of proposal for a theoretical foundation of rights can contribute to highlight the inconsistency of the reasoning model underlying several decisions of the constitutional courts, while laying the foundations for an alternative conception of them, within a vision aimed at restoring the primacy of the ethical dimension of rights over other needs (starting from socioeconomic processes).

\section{REFERENCES}

ABRAMOVICH, Victor; COURTIS, Christian. Los derechos sociales como derechos exigibles. Madrid: Trotta, 2004.

AI-THU, Dhang. Libéralisme et justice sociale : la clause lockéenne des droits de propriété. Revue française d'économie, v. 10, n. 4, p. 205-238, 1995.

BAYLES, Michael. Hart's Legal Philosophy. An Examination. Dordrecht: Kluwer, 1992.

BERLIN, Isaiah. Two concepts of liberty: an inaugural lecture delivered before the University of Oxford on 31 October 1958. Oxford: Oxford Clarendon Press, 1958.

BESSON, Samantha. The Morality of Conflict. Reasonable Disagreement and the Law. Oxford: Hart, 2005.

BIN, Roberto. Diritti e fraintendimenti. Ragion Pratica, n. 14, p. 15-25, 2000.

BOBBIO, Norberto. "L'età dei diritti" [1989]. In: BOBBIO, Norberto. L'età dei diritti. Einaudi: Torino, 1992.

\footnotetext{
${ }^{52}$ See in particular (HOLMES; SUNSTEIN, 1999; BIN, 2000; DICIOTTI, 2006, p. 86 ff.; POSNER, 2014; HÄBERLE, 2019).

${ }^{53}$ For a criticism of the project to extend the economic methodology to the analysis of the political processes and to the foundation of human rights, see in particular Rawls (1999, p. 317).
} 
BUCHANAN, James M.; TULLOCK, Gordon. The Calculus of Consent. Logical Foundations of Constitutional Democracy. Ann Arbor: University of Michigan Press, 1962.

CRANSTON, Maurice. Human Rights, Real and Supposed. In: RAPHAEL, D. D. (ed.). Political Theory and Rights of Man. London: Macmillan, 1967.

BARBALET, Jack M. Citizenship: Rights, Struggle and Class Inequality. London: Open University Press, 1988.

CELANO, Bruno. I diritti nella Jurisprudence anglosassone contemporane. In: COMANDUCCI, P.; GUASTINI, R. Analisi e diritto 2001. Ricerche di giurisprudenza analitica. Torino: Giappichelli, 2001.

CELANO, Bruno. I diritti nello Stato costituzionale. Bologna: Il Mulino, 2013.

CIANCIARDO, Juan. El conflictivismo en los derechos fundamentales. Pamplona: Eunsa, 2000.

CORSO, Guido. Diritti umani. Ragion pratica, n. 7, p. 59-66, 1996.

CRUZ PARCERO, Juan A. El lenguaje de los derechos. Ensayo para una teoría estructural de los derechos. Madrid: Trotta, 2007.

DE OTTO, Ignacio. La regulación del ejercicio de los derechos y libertades. La garantía de su contenido esencial en el artículo 53.1 de la Constitución. In: MARTÍNRETORTILlO, Lorenzo (a cargo de). Derechos fundamentales y Constitución. Madrid: Tecnos, 1988.

DICIOTTI, Enrico. Il mercato delle libertà: l'incompatibilità tra proprietà privata e diritti. Bologna: Il Mulino, 2006.

FABRE, Cécile. Social Rights Under the Constitution. Government and the Decent Life. New York: Oxford University Press, 2004.

FACCHI, Alessandra. Diritti fantasma? Considerazioni attuali sulla proliferazione dei soggetti. Ragion pratica, n. 31, p. 313-336, 2008.

FANLO CORTÉS, Isabel. I bambini e i diritti. Una relazione problematica. Torino: Giappichelli, 2008. 
Anti-conflictualist and liberal minimalism of rights: an analysis from the perspective of interest theory and the dynamic approach

FEINBERG, Joel. The Nature and Value of Rights. Journal of Value Inquiry, n. 4, p. 243-257, 1970.

FEINBERG, Joel.. Social Philosophy. New Jersey: Prentice-Hall, 1973.

FERRAJOLI, Luigi. Diritti fondamentali. Teoria politica, n. 14, 2, 1998, p. 3-34.

FERRAJOLI, Luigi. Diritti fondamentali: un dibattito teorico, a cura di E. Vitale. Roma-Bari: Laterza, 2001.

FERRAJOLI, Luigi. Principia iuris. Teoria del diritto e della democrazia. Roma-Bari: Laterza, 2007. v. I.

FERRAJOLI, Luigi. La democrazia attraverso i diritti. Il costituzionalismo garantista come modello teorico e come progetto politico. Roma-Bari: Laterza, 2013.

FERRAJOLI, Luigi. La logica del diritto. Dieci aporie nell'opera di Hans Kelsen. Roma-Bari: Laterza, 2016.

FINNIS, John. Natural Law and Natural Rights. Oxford: Oxford Clarendon Press, 1980.

FRIED, Charles. Right and Wrong. Cambridge (Massachusetts): Harvard University Press, 1978.

GRIFFIN, James. On Human Rights. Oxford: Oxford University Press, 2008.

HÄBERLE, Peter. Los derechos fundamentales en el Estado prestacional. Lima: Palestra, 2019.

HABERMAS, J. Between facts and norms: contributions to a discourse theory of law and democracy [1992]. Cambridge: The Mit Press, 1996.

HABERMAS, J. Die Zukunft der menschlichen Natur. Auf dem Weg zu einer liberalen Eugenik? Frankfurt am Main: Suhrkamp, 2001.

HART, Herbert L. A. Legal Rights [1973], republ. In: HART, Herbert L. A. Essays on Bentham. Studies in Jurisprudence and Political Theory. Oxford: Oxford Clarendon Press, 1982.

HART, Herbert L. A. Between Utility and Rights. Columbia Law Review, v. 79, n. 5, p. 828-846, 1979. 
HART, Herbert L. A. . Definition and Theory in Jurisprudence [1953], in Essays in Jurisprudence and Philosophy. Oxford: Oxford Clarendon Press, 1983.

HART, Herbert L. A. . Are There Any Natural Rights? [1955]. In: WALDRON, J. (ed.). [S.l.: s.n.], 1984.

HAYEK, Friedrich von. Law, legislation and liberty. London: Routledge and Kegan Paul, 1982.

HOLMES, Stephen; SUNSTEIN, Cass R. The Cost of Rights: Why Liberty Depends on Taxes. London: Norton \& Company, 1999.

IGNATIEFF, Michael. Human Rights as Politics and Idolatry. Oxford: Princeton University Press, Princeton, 2001.

JIMÉNEZ CAMPO, Javier. Derechos fundamentales. Concepto y garantías. Madrid: Trotta, 1999.

KAMM, Frances M. Conflicts of Rights: Typology, Methodology and NonConsequentialism. Legal Theory, n. 7, p. 239-255, 2001.

KRAMER, Matthew H. John Locke and the Origins of Private Property: Philosophical Explorations of Individualism. Cambridge: Cambridge University Press, 1997.

KRAMER, Matthew H.. Rights without Trimmings. In: SIMMONDS, N. E.; STEINER, H. (ed.). A Debate over Rights. Philosophical Enquiries. Oxford: Oxford University Press, 1998.

LYONS, David. Rights, Claimants and Beneficiaries [1969]. In: LYONS, David. Rights, Welfare, and Mill's Moral Theory. New York: Oxford University Press, 1994.

MACCORMICK, Neil. Children's Rights: a Test-Case for Theories of Rights. Archiv für Rechts - und Sozialphilosophie, n. 62, p. 305-316, 1976.

MACCORMICK, Neil. Rights in Legislation. In: HACKER, P.; RAZ, J. (ed.). Law, Morality and Society. Oxford: Oxford Clarendon Press, 1977.

MACCORMICK, Neil. Legal Right and Social Democracy. Essays in Legal and Political Philosophy. Oxford: Oxford Clarendon Press, 1982.

MACCORMICK, Neil. Coherence in Legal Justification. In: A. PECZENIK et al. (ed.). Theory of Legal Science. Dordrecht: Reidel, 1984.

MACCORMICK, Neil. Institutions of Law. An Essay in Legal Theory. Oxford: Oxford 
Anti-conflictualist and liberal minimalism of rights: an analysis from the perspective of interest theory and the dynamic approach

University Press, 2007.

MACPHERSON, Crawford B. The Political Theory of Possessive Individualism: Hobbes to Locke. Oxford: Oxford University Press, 1962.

MARMOR, Andrei. On the Limits of Rights. Law and Philosophy, v. 16, n. 1, p. 1-18, 1997.

MARSHALL, Thomas H. Citizenship and social class [1950]. London: Pluto Press, 1992.

MARTÍNEZ PUJALTE, Antonio L. La garantía del contenido esencial de los derechos fundamentales. Madrid: Centro de Estudios Constitucionales, 1997.

MORESO, José J. Conflictos entre principios constitucionales. In: Id. (a cargo de), Neoconstitucionalismo(s). Madrid: Trotta, 2003.

MORESO, José J. Dos concepciones de la aplicación de las normas de derechos fundamentales. In: BETEGÓN, J. et al. (a cargo de). Constitución y derechos fundamentales. Madrid: Centro de Estudios Políticos y Constitucionales, 2004.

NAGEL, Thomas. Mortal questions [1979]. Cambridge: Cambridge University Press, 2013.

NINO, Carlos S. Ética y derechos humanos Un ensayo de fundamentación [1984]. Buenos Aires: Astrea, 1989.

NOZICK, Robert. Anarchy, State, and Utopia [1974]. New York: Wiley-Blackwell, 2011.

OFFE, Claus. Contradictions of The Welfare State. Cambridge, Massachusetts: The Mit Press, 1984.

OLLERO TASSARA, Andrés. La ponderación delimitadora de los derechos humanos: libertad informativa e intimidad personal. Pensamiento y Cultura, n. 3, p. 157-166, 2000 .

O’NEILL, Onora. The Dark Side of Human Rights. International Affairs, n. 81, 2, p. 427-439, 2005.

PERELMAN, Chaïm. Peut-on fonder les droits de l'homme?. In: PERELMAN, Chaïm. Droit, morale et philosophie. Paris : Librairie générale de droit et de jurisprudence, 1968. p. 57-64. 
PINTORE, Anna. I diritti della democrazia. Roma-Bari: Laterza, 2004.

POSNER, Richard A. The Twilight of Human Rights Law. Oxford: Oxford University Press, 2014.

PRIETO SANCHÍS, Luis. Ley, principios, derechos. Madrid: Dykinson, 1998.

RAWLS, John. Theory of Justice: Revised Edition [1971]. Cambridge, Massachusetts: Harvard University Press, 1999.

RAWLS, John. The Law of Peoples with. The Idea of Public Reason Revisited. Cambridge, Massachusetts: Harvard College, 1999.

RAZ, Joseph. The Nature of Rights [1984], repub. In: RAZ, Joseph. The Morality of Freedom. Oxford: Oxford Clarendon Press, 1986. p. 165-192.

RAZ, Joseph. Legal Rights [1984], repub. In: RAZ, Joseph. Ethics in the Public Domain. Oxford: Oxford Clarendon Press, 1994.

RODOTÀ, Stefano. Repertorio di fine secolo. Roma-Bari: Laterza, 1992.

SEN, Amartya. Resources, Values and Development. Harvard: Harvard University Press, 1984.

SERNA BERMÚDEZ, Pedro; TOLLER, Fernando M. La interpretación constitucional de los derechos fundamentales: una alternativa a los conflictos de derechos. Buenos Aires: La Ley, 2000.

SMITH, Tara. Rights Conflicts. The Undoing of Rights. Journal of Social Philosophy, n. 26, p. 141-158, 1995.

STEINER, Hilley. The Structure of a set of Compossible Rights. Journal of Philosophy, v. 74 , n. 12 , p. $767-775,1977$.

SUMNER, Leonard W. The Moral Foundation of Rights. Oxford: Oxford Clarendon Press, 1987.

TROPMAN, John E. American Values and Social Welfare: Cultural Contradictions in the Welfare State. Englewood Cliffs, New Jerse: Prentice-Hall, 1989.

TULLY, James. A Discourse on Property: John Locke and His Adversaries. Cambridge: Cambridge University Press, 1980. 
Anti-conflictualist and liberal minimalism of rights: an analysis from the perspective of interest theory and the dynamic approach

VON JHERING, Rudolf . Geist des römischen Rechts. Lipsia: Breitkopf und Härte, [1878]. v. 3.

WALDRON, Jeremy. The Right to Private Property. Oxford: Oxford Clarendon Press, 1988.

WALDRON, Jeremy. Two Worries About Mixing One's Labour. The Philosophical Quarterly, v. 33, n. 130, p. 37-44, 1983.

WALDRON, Jeremy (ed.). Theories of Rights. Oxford: Oxford University Press, 1984.

WALDRON, Jeremy. Rights in Conflict [1989]. In: WALDRON, Jeremy. Liberal Rights: collected papers 1981-91. Cambridge: Cambridge University Press, 1993.

WALDRON, Jeremy. Nozick and Locke: Filling the space of rights. Social Philosophy and Policy, v. 22, n. 1, p. 81-110, 2005.

WELLMAN, Carl. An Approach to Rights: Studies in the Philosophy of Law and Morals. Dordrecht: Kluwer, 1997.

WELLMAN, Christopher On Conflicts between Rights, The Proliferation of Rights. Moral Progress or Empty Rhetoric?, Boulder: Westview, 1999.

WOLFF, Jonathan. Robert Nozick: Property, Justice, and the Minimal State. Stanford: Stanford University Press, 1991.

ZOLO, Danilo. La strategia della cittadinanza. In: ZOLO, Danilo. (a cura di). La cittadinanza. Appartenenza, identità, diritti. Laterza, Roma-Bari, 1994.

Como citar este documento:

ZEZZA, Michele Beniamino. Anti-conflictualist and liberal minimalism of rights: an analysis from the perspective of interest theory and the dynamic approach. Revista Opinião Jurídica, Fortaleza, v. 19, n. 30, p.149-174, jan./abr. 2021. 